\title{
CONVERSIONI: VERSO UN NUOVO MODO DI CREDERE? EUROPA, PLURALISMO, ISLAM
}

Conversions: towards a new way of believing? Europe, pluralism, Islam

\author{
ALLIEVI, Stefano. Napoli: Guida editori, 2017, 190 p.
}

Roberto Marinucci*

O livro Conversioni: verso un nuovo modo di credere? de Stefano Allievi - sociólogo e professor da Universidade de Pádua, Itália - é uma significativa contribuição aos estudos do fenômeno religioso contemporâneo, envolvendo numerosos nexos com a temática da mobilidade humana. Produto de estudos e pesquisas realizados no decorrer das últimas décadas, o livro aborda especificamente o tema das conversões - ao Islã - individuais, contemporâneas, relacionadas principalmente ao mundo ocidental europeu.

A escolha do objeto de pesquisa é justificada pelos desafios atrelados à difusão do Islã na Europa - continente tradicionalmente "bianco, occidentale e cristiano" (p. 11) -, pela importância do fenômeno da conversão que, sociologicamente falando, envolve a temática mais ampla das transformações identitárias em uma sociedade globalizada e em movimento, e, por fim, pela relevância da reinterpretação do fenômeno religioso na contemporaneidade.

O primeiro capítulo do livro desenvolve um estado da arte das principais abordagens sociológicas do fenômeno religioso. O autor sublinha o caráter "estático" das teorias tradicionais sobre religião, o que acarreta evidentes limites conceituais na intelecção das conversões que ocorrem nas sociedades hodiernas. Nesta parte, são abordadas também as principais características do fenômeno religioso contemporâneo no mundo ocidental, focalizando, principalmente, a secularização, a privatização e, sobretudo, a pluralização de identidades e pertencimentos. Merece um destaque o tema da pluralização, pois a difusão de conversões e eventos análogos pressupõe - e incentiva uma oferta religiosa não monopolística. O tema da identidade é também

Editor-chefe da revista REMHU, Centro Scalabriniano de Estudos Migratórios (CSEM). Brasília DF, Brasil. E-mail: remhu@csem.org.br. Orcid: 0000-0002-2042-2628. 
abordado enquanto "processo" e fruto de escolhas, num contexto onde são cada vez mais raras as identidades religiosas "herdadas".

O segundo e terceiro capítulos apresentam, de forma sistemática e crítica, as várias interpretações e tipologias da conversão, definida, em termos gerais, como uma "riorganizzazione radicale di identità, significato e vita" (p. 50), que pode ser repentina ou progressiva, voluntária (volitional type) ou "passiva" (self-surrender type), e que envolve um "cambiamento dell'universo di discorso" (p. 51), ainda que não necessariamente uma mudança de denominação religiosa. Allievi se debruça também na espinhosa questão das causas da conversão, com a constante preocupação em evitar reducionismos e atentando sobre o protagonismo dos sujeitos e a diversificação das ofertas religiosas.

A seguir, o autor apresenta uma extensa tipologia das conversões, a partir de estudos e pesquisas realizados com covertidos europeus ao Islã. As dimensões "relacional" e "racional" são apontadas como fatores desencadeadores do processo. Entre outros aspectos, o autor sublinha o fenômeno das "conversões instrumentais" vinculadas à mobilidade humana, como no caso das pessoas que buscam a conversão visando facilitar a obtenção do reconhecimento do status de refugiado ${ }^{1}$. Mas há também conversões - neste caso, "não instrumentais" - que decorrem de "encontros", principalmente em ocasião de viagens para o exterior ou contatos com imigrantes. Em relação a esse último ponto, é interessante a reflexão relacionada às conversões que surgem em virtude da mixité (diversificação cultural, étnica e religiosa da população), sobretudo no ambiente escolar, onde a presença de muçulmanos na Europa é cada vez mais comum. Outro tema relevante são as conversões em chave radicalizada, reivindicativa e opositiva. Há vários estudos ${ }^{2}$ sobre essa temática que mostram como a busca das raízes - a radicalização -, entre os convertidos mas também entre os imigrantes, revela e, ao mesmo tempo, fortalece a autonomia da pessoa, que se autointerpreta como construtora do próprio processo identitário, para além das heranças culturais e religiosas, o que aponta também para uma mudança substancial em relação ao Islã dos países de origem.

Tais temáticas são ulteriormente desenvolvidas no quinto capítulo, não muito extenso, mas certamente o mais interessante na ótica da mobilidade humana. O Islã diaspórico e sua relação com o Islã dos países de origem, o surgimento de um "Islã europeu", o papel dos convertidos europeus na

1 Sobre essa questão cabe citar o trabalho de Shoshana Fine (2013) em relação às conversões ao cristianismo de muçulmanos em trânsito na Turquia, com vistas a assumir um perfil identitário que corresponda aos interesses dos países receptores e facilite o ingresso e a obtenção de documentação.

2 Por exemplo, Nagra (2011), Yang, Ebaugh (2001) e Campani (2006). 
configuração desse Islã diaspórico, são alguns dos temas aprofundados nessa seção. No "eixo" formado pela i) sociedade ocidental, ii) as pessoas ocidentais convertidas ao Islã, iii) os muçulmanos imigrantes que vivem no mundo ocidental e iv) as sociedades dos países de origem desdobram-se um conjunto de interconexões complexas, em que entram em jogo diferentes interesses e relações de poder. As reflexões de Allievi sobre o papel de cada ator desse eixo envolvem desdobramentos valiosos, sobretudo no que diz respeito ao papel dos convertidos ocidentais que, por sua visão "geo-religiosa" e "geo-culturale" (p. 142), podem se tornar mediadores entre os imigrantes e a sociedade ocidental; mas também no que toca aos imigrantes que, influenciados pelo Islã diaspórico, podem encabeçar novas relações e, talvez, transformar o Islã dos países de origem.

O vínculo entre convertidos ocidentais e imigrantes muçulmanos é, por vezes, tenso. Conforme o testemunho de um convertido: "Una delle grossissime difficoltà che io ho avuto per molti anni era che loro non volevano islamizzarmi, loro volevano arabizzarmi" (p. 145), ressaltando um dos nós mais comuns enfrentados pelos convertidos - mas possivelmente também pelas segundas e terceiras gerações de migrantes -, ou seja, a relação entre a dimensão cultural e aquela religiosa do Islã ${ }^{3}$. Seja como for, esse tenso vínculo entre imigrantes e convertidos, certamente, implica uma recíproca retroalimentação que pode levar, inclusive, à transformação do Islã dos imigrantes, principalmente das segundas e terceiras gerações.

A leitura do livro de Allievi abre muitas pistas de reflexão para a compreensão da dimensão religiosa em contextos diapóricos; auxilia para uma abordagem menos preconceituosa em relação ao Islã; e possibilita também um aprofundamento das dinâmicas de hibridização produzidas pela pluralização das sociedades ocidentais, o que desmascara a ideia tradicional de que "ad un popolo e ad un territorio corrisponde[va] una religione" (p. 167).

\section{Referências bibliográficas}

FINE, Shoshana. The Christianisation of Afghan and Iranian transit migrants in Istanbul: encounters at the biopolitical border. COMPAS, Working Paper, n. 104, University of Oxford, 2013.

\footnotetext{
3 Merece ser citado, em relação a essa questão, o trabalho de Sarai Samper Sierra (2003) acerca de mulheres migrantes muçulmanas na Espanha. Segundo a autora, a mulher marroquina envolvida no mercado de trabalho tende a relativizar "el sentido de muchas de las costumbres del país de origen que en la sociedad receptora dejan de ser funcionales. La inmigrante traza la línea que distingue el islam de las costumbres propias de su país" (2003, p. 129). Mas não é um processo simples e linear, inclusive por causa das interferências e das pressões do ambiente social de referência.
} 
CAMPANI, Giovanni. Perché siamo musulmane. Voci dai cento Islam in Italia e in Europa. Milano: Guerini, 2006.

NAGRA, Baljit. "Our Faith Was Also Hijacked by Those People": Reclaming Muslim Identity in Canada in a Post-9/11 Era. Journal of Ethnic and Migration Studies, v. 37, n. 3, p. 425-441, 2011.

SAMPER SIERRA, Sarai. Procesos de transformación de las creencias religiosa entre las mujeres inmigrantes marroquíes en España. Migraciones, n. 13, p. 107-136, 2003.

YANG, Fenggang; EBAUGH, Helen Rose. Transformations in New Immigrant Religions and Their Global Implications. American Sociological Review, v. 66, p. 269-288, 2001. 